\title{
Assessing Community-based Natural Resources Management at Lake Naivasha, Kenya
}

\author{
Usman Isyaku (Corresponding author) \\ Department of Geography, Ahmadu Bello University, Zaria, Nigeria \\ Tel: 234-806-941-3003 E-mail: ussy019@yahoo.com \\ Murtala Chindo \\ Department of Geography, University of Leicester, United Kingdom \\ Tel: 44-784-602-8183 E-mail: murtalachindo@yahoo.com
}

Mukhtar Ibrahim

School of Basic and Remedial Studies, Ahmadu Bello University, Funtua, Nigeria

Tel: 234-803-607-3776 E-mail: mukhee2002@yahoo.com

\author{
Received: October 17, 2011 \\ Accepted: November 12, $2011 \quad$ Published: December 1, 2011 \\ doi:10.5539/enrr.v1n1p106 \\ URL: http://dx.doi.org/10.5539/enrr.v1n1p106
}

\begin{abstract}
Lake Naivasha became a focus of international attention when it attained a Ramsar status in 1995. The lake is the major source of freshwater for the Kenya's booming horticultural industry. There is growing evidence of excessive water abstraction to meet both the economic and social needs of communities living around the lake. Recently its management and conservation has been devolved to the local communities in a bottom-up participatory approach to replace the traditional top-down management strategy. This paper assesses the role of Community-Based Natural Resources Management (CBNRM) in achieving sustainable water management at Lake Naivasha. The results showed a diversity of stakeholders with different interests competing amongst themselves for water access which is affecting both the lake hydrology and the surrounding wetland ecosystems. Due to human activities, the effects of climate change, and the lack the capacity of various stakeholders to finance and follow through with conservation projects, the lake water has been drying over the years.
\end{abstract}

Keywords: Community, Participation, Conservation, Sustainability, Devolution

\section{Introduction}

Lake Naivasha is Kenya's second largest freshwater located in Naivasha about $80 \mathrm{Km}$ northwest of Nairobi, within the Nakuru District of Rift valley Province. The lake, shown in Figure 1 is lying at 1880 meters above sea level with a surface area of 139 square kilometers (Arusei et al., 2003). This area is surrounded by swamps estimated to be around 64 square kilometers; the inflow to the lake comes mainly from Aberdare Mountains and the lake has no outflow (Vincent et al., 1979). The Lake, originally named Nai'posha by Maasai means 'rough water' because of occasional storms, is now one of the few African rivers that have achieved global significance as a Ramsar and UNESCO HELP (Hydrology Environment Life and Policy) status. It was also declared an Eco-hydrology Demonstration site in 2005 (Harper \& Mavuti, 2004). As a result, it is now both a national and international conservation area. Recent publications about the present state of the lake portray a gloomy picture with an unsustainable future.

To keep pace with the rapidly growing population, the lake has become a major source of water supply for both domestic and agricultural activities. It also sustains the horticultural industry, which is the country's third main source of income after agriculture and tourism. Over the years, evidences have shown large scale disruption of the lake's ecosystem through the introduction of exotic species which has affected the aquatic food chain (Harper et al., 2004). Excessive human activity has led to deterioration in the quantity and quality of the lake water and the surrounding ecosystems. Pollution of the water decreased fish yield, and encroachment into the 
riparian areas has destroyed the papyrus swamps which serve as a buffer that filter sediments draining into the lake (Harper et al., 1990). In addition, over abstraction of both surface and ground water, damming of rivers along the upper catchment, as well as diversion of tributaries (Harper et al., 1990; Harper, 2002) have contributed to the reduction in the level of the lake by about $4 \mathrm{~m}$ compared to its $1960 \mathrm{~s}$ level (Harper, 2002). The groundwater abstraction by geothermal industries and their discharge of effluents into the lake is also having adverse effects on the lake ecosystem. Collectively, these factors have become a serious socio-economic and ecological problem of great concern to researchers and the local communities surrounding the lake.

\section{Community-Based Approach in Natural Resources Management}

Natural Resources Management has witnessed a paradigm shift over the last two decades from the traditional command and control top-down approach to community participation (Shackleton et al., 2002). The top-down proponents assume that the responsibility of resource management should be handled by experts who have a better knowledge of how it should be managed (Bookrags, 2001, Carr, 2002). It was later discovered that such state-run conservation strategy has failed to reflect local realities of the targeted communities (see Brown, 2002). The perceived failure and limitations of the traditional top-down, experts' oriented approach led to the emergence of Community Based Natural Resource Management (CBNRM) as a bottom-up approach in natural resources management (Jordan, 2003; Shmigel, 2005). This approach is aimed at the devolution of decision making power to the grass root communities over the use and management of their own natural resources (Nhantumbo et al., 2003).

Devolution as a concept in resources management has its origin in "The Ecologists" report of 1972 and became popular by Schumacher's (1973) famous "small is beautiful". The Brundtland Report (1987) and the Rio Earth Summit (1992) have also advocated the decentralisation of resource management to the local communities under government supervision. The term CBNRM was defined by Pretty \& Guijt (1992:22) as a: "process by which local groups or communities organise themselves with varying degrees of outside support so as to apply their skills and knowledge to the care of natural resource and environment while satisfying livelihood needs". A broad, encompassing and inclusive definition of CBNRM was provided by CBNRM.Net (2011): "CBNRM is the management of natural resources under a detailed plan developed and agreed to by all concerned stakeholders. The approach is community-based in that the communities managing the resources have the legal rights, the local institutions, and the economic incentives to take substantial responsibility for sustained use of these resources. Under the natural resource management plan, communities become the primary implementers, assisted and monitored by technical services". As a bottom-top approach, the CBNRM attempts to assist local communities reduce poverty through sustained use of their natural resources. To realise this aim, a number of projects were initiated to offer financial and technical support to empower communities (by knowledge and skills) to take responsibility for the management of their resources and the environment.

As noted earlier, the effort for CBNRM was spear-headed and funded by transnational NGOs and multilateral funding organisations devoted to work and research on natural resources. Even so, many CBNRM projects have been under criticism for their failure to achieve the desired objectives to the target communities resulting in the collapse of many CBNRM projects even at take-off stage (Fabricius, 2004). This failure can be attributed to shortage of social, human, physical and financial capital necessary for their successful implementation (Fabricius et al., 2007). Other reasons attributed to the failure are non-comprehensive monitoring and evaluation of the CBNRM programmes, and poor supportive role of local governments and local elites. Ignoring gender roles can also lead to loss in local knowledge. For conservation and development to be achieved simultaneously, a number of authors have called for de-emphasising the overwhelming role of the communities in conservation (e.g. Barrett, et al., 2006), others are advocating for harmonising both top-down and bottom-up approaches (e.g. Berkes, 2007).

For sustainable and integrated water resource management to be achieved at Lake Naivasha, the role of the community living around the lake and their overdependence on it for their livelihood must be investigated. Because there are various groups of stakeholders around the Lake who claim to champion the cause of sustainable environment and resource use. This study assesses CBNRM as a sustainable management strategy in one of Kenya's most dependent natural resources.

\section{Methods}

\subsection{Sources of Data}

This research used both primary and secondary data sources. The primary source is based on collection of some semi-structured interviews conducted in Kenya on behalf of the Lake Naivasha research group of the University of Leicester in 2009. Interviewees were selected across the major stakeholder groups and most of them are 
members of the Executive committees representing their respective organisations. Interviews were conducted with the local fishermen, boatmen, small-scale business men, tourist operators, flower farm employees and local youth organisations. Multiple interviews were conducted and recorded on tapes, and each lasted for the average of 30 minutes or more depending on the participant's ability to articulate his views. Materials which include published journal articles, unpublished dissertations, internet materials and text books constitute secondary data source.

\subsection{Data Analysis}

Qualitative methodology was used for this study and Grounded theory was selected because interviews constitute the main source of data. This method was first developed by two sociologists, Glaser and Strauss (1967) to generate inductive theories from data. It involves the use of constant comparisons and coding paradigm for conceptual development of theories. It is based on the premise that theory at various levels of generality is significant for gaining a deeper knowledge of a social phenomenon (Glaser \& Strauss, 1967; Glaser, 1978).

The interview tapes were first transcribed with the aid of Express Scribe software. After the transcription was completed, an iterative process of coding began. Open coding was done using a highlighter to mark sentences or paragraphs giving it a code and the same time writing the code name by the side of the paper. This is followed by axial coding in order to generate categories by grouping various codes around a common word with greater explanatory power. At the same time memos are written as records of analytic and conceptual meaning of words or statements. The process was repeated until saturation point - meaning no new codes or categories were generated. The emergent themes form the findings for the study that are presented and discussed in the following section.

\section{Results and Discussion}

\subsection{Environmental Status and Conservation of the Lake}

Communities around Naivasha benefit from the ecosystem services the lake and the surrounding riparian land provide. These services range from provision of fish foods, water for domestic consumption, employment opportunities, and other indirect benefits such as tourism and recreation. Table 1 details the benefits Naivasha community derive from the lake. From the table, about 31 per cent of the respondents who are mostly fishermen said the lake serves as a major source food. While 26 per cent involved in small scale businesses said they derive other indirect benefits from the lake such as drainage, domestic or industrial water supply. Among the fishermen, about 18 per cent of them said they depend on the lake as source of income through the sale of fish or recreational services. About 16 per cent comprising of both the fishermen and small scale businesses men said they depend on the lake for domestic water supply. While only a few proportions of them derive benefits through employment tourism and recreation opportunities.

Respondents' opinion was sought on the changes in the hydrological status of the lake. Almost all the respondents perceived the lake water to be drying up while only a few representing less than 10 per cent are not sure whether there is any change in the water level. This implies that there is a serious environmental degradation at Lake Naivasha which is affecting the hydrological status of the lake. A number of scientific evidences have been presented to show the degradation of the Lake. For example, in 2006, David Harper's presentation at the Fourth World Water Forum indicates that: "the lake level has dropped by three meters from its maximum, the area has shrunk to half its size, and precious wetlands are degraded beyond recognition". Furthermore, "the ever-smaller lake is becoming an over-enriched muddy pool, which shortly will become unusable through the development of toxic blue-green algae blooms. Its inflowing rivers, formerly sparkling and permanent are now muddy and unpredictable" (Wild Life Extra.com, 2011:1).

From the results presented in Table 2, majority of the respondents reported that drought is the major factor responsible for the lake drying, while about 23 per cent blame it on water abstraction for irrigating the flower farms. About 20 per cent reported that excessive water abstraction for both agricultural and domestic uses is the major cause, while some said it is due to catchment and habitat destruction. Since this problem is imminent, the study in the next section sought after the likely barriers against conserving the lake and the surrounding ecology.

\subsection{Barriers to Community Conservation Activities}

The major barrier to the community activities around Lake Naivasha is inadequate funding. According to all the respondents, most of the stakeholder organisations are faced with serious financial problems that hindered their capacity to execute their projects. Adequate funds are needed to recruit more staff, pay for other logistics, purchase of office equipment and transportation. Money is usually raised through the payment of annual subscription by members which most of the respondents said is insufficient to run an organisation. Depending on 
the membership status of the subscriber, the subscriptions vary from 2000 Kenyan Shillings for individual members to 5000 Kenyan Shillings for corporate bodies or companies. In some cases, funding is sought through the competitive process of submitting proposals to international donors like WWF (World Wildlife Fund) and IUCN (International Conservation Union), development partners, embassies and Kenyan government. For example, in 2008 LNRA (Lake Naivasha Riparian Association) was able to raise 16 million shillings to fund its projects through this means.

Another barrier is the failure of the organisations to coordinate their activities together. Some respondents argued that the multi-sectoral problem facing the lake and its environments requires a holistic approach and coordination. For example, the fisher folks, pastoralists, growers, riparian land owners and the local communities at the upper and lower catchments must be involved in conservation efforts. Otherwise the activity of one group may undermine the efforts of another group. In some few cases however, some of the organisations come together, for example in 2009, LNRA and LNGG (Lake Naivasha Growers Group) formed a common group called LNCF (Lake Naivasha Conservation Forum) with the aim of coordinating their activities but they recently became separated as a result of financial problems and disagreements over LNGG's partnership with LANAWRUA (Lake Naivasha Water Users Association). This implies that a lasting coordination of the interest groups in very difficult to achieve despite sharing common objectives.

Respondents from the fisheries department disclosed that poverty and illiteracy hinders the activities of their organisation. The fisher folks for example lack the knowledge of how to undertake sustainable fishing. They also interfere with papyrus growing on the water body which serve as the breeding sites for fish. And most of the local people are poor and cannot join any organisation because they are unable to pay the annual subscriptions. To some organisations, the problem is their inability to enforce their codes of practice. There is evidence of widespread violation of conservation laws, non-compliance with the Water Act, fisheries, forest, wildlife and forest regulations around the Lake but these organisations lack the authority to implement such laws. For example a respondent highlighted that sometimes the pastoralists graze their animals around the riparian land and destroy the vegetation and the LNRA lacks the authority to prosecute them. However, the pastoralists always argue that the riparian land remains the only available option for feeding their animals. Respondents further complained that the authorities who are responsible for enforcing the laws are inefficient and biased in discharging their duties. Many of them accuse the law enforcement bodies of corruption and selective justice in favour of other groups of stakeholders.

\subsection{Evaluating CBNRM at Lake Naivasha}

The conceptual model developed by Nhantumbo et al. (2003) to evaluate CBNRM in Mozambique did not fit the situation at Lake Naivasha. Instead a modified model base on land tenure system, adequate funding, adaptive capacity, stakeholder collaboration and access to information was developed and used in this case study. Using the model (Figure 3) for evaluation, the following can be highlighted as the main reasons for CBNRM failure at Naivasha.

First, the existing land tenure system is biased towards the investors' interest which becomes a reason for stakeholder conflict. Interview accounts have proved that land is not equitably distributed between the various communities at Naivasha. The indigenous Masaai pastoralists are marginalised in terms of land rights, and as a consequence they are left with a few numbers of access routes to the lake. Funding is another major setback to the success of CBNRM at Naivasha because the communities lack adequate financial capacity to fund necessary conservation projects. The Kenyan government has devolved power to the communities without providing them with financial support. An alternative source of funding from the international donors is very competitive to obtain and usually insufficient to finance long term projects. Second, the communities are mostly poor and illiterates as such they lack the intellectual capacity to manage their resources in a sustainable way. For example according to the interviews, more than 500 fisher folk families depend on the lake as a source of livelihood thereby adding more pressure on the depleting fish resource. Therefore the local community lack adaptive co-management skills to cope with issues of climate change and other natural disasters. Absent of collaborative participation among the stakeholders is another barrier. The multiplicity of stakeholder groups makes partnership and coordination very difficult. According to the interviews, many stakeholders are consistently marginalised and this resulted into mistrust and suspicion between them. Third, policy formulation is not based on factual scientific information. For example the interviews shows that the water abstraction survey conducted by LANAWRUA in partnership with WRMA (Water Resource Management Agency) that is supposed to form the basis for allocation of water permits, is yet to be completed and integrated into a policy document. 
The CBNRM model practiced at Lake Naivasha has failed to provide a sustainable management of the lake and the surrounding catchment because there is no efficient water use. Both the lake and groundwater are over abstracted to irrigate flower farms and to supply the surrounding Naivasha town with domestic water. According to the interviews, the lake is constantly polluted by the sewage discharge from the Naivasha Municipality as well as the drainage of pesticides and other agro-chemicals from the surrounding flower farms. In March 2010, it was reported by the local community that the fish from the lake is dying on a large scale. This issue became a subject of debate about the possible causes of this incident. A respondent who is a member of LANAWRUA said that this ecological problem is happening for the first time. The government officials issued a statement that the fish death is a result the reduced level of dissolved oxygen caused by eutrophication and algal boom. But the issue is still a subject of debate and accusations at Naivasha. The amount of fish has dropped significantly due to over fishing because more than 500 fishermen families depending on the lake for their livelihood. Interview account also shows that the water level has dropped to a low record in history due to siltation and obstruction and diversion of the flow of water from the upper catchment. The riparian land encroachment and over grazing by livestock has destroyed the papyrus vegetation which serves as a buffer against siltation and habitat for wildlife. Forest resources are continuously degraded; trees have been cut and eventually increase surface run-off and erosion. These findings support the works of (Morrison \& Harper, 2009; Billgren \& Holmen, 2008; Becht et al, 2006; Becht \& Harper, 2002) that the environment around Lake Naivasha is degrading.

However, despite the failure of CBNRM, interview accounts have highlighted some progress achieved through the involvement of local communities in a number of environmental conservation projects as reported by Becht et al. (2006). Both local and international NGOs such as LNRA, LNGG, and Greenbelt Movement have launched eco-friendly conservation programmes. For example since its creation in 2002, a local group called Youth of Naivasha Forum (YONAF) has been involved in tree planting exercise and garbage collection. Other similar groups like Mars Investment Group and Integrity Youth Group are also involved in the sanitation and tree planting. The fisheries department has also embarked on sensitization campaign against over exploitation of fish as well as training local fishermen on how to practice aquaculture. Community members receive motivation from their organisations through monetary donations to members that implement and maintain sustainable environmental practices. In addition, benefit is also derived from community empowerment programmes aimed at training them to manage their business effectively or to diversify their sources of income.

\section{Conclusion}

In natural resources management the bottom-up participatory approach has been widely practiced over the last three decades in place of the traditional top-down experts-oriented approach. This co-management strategy involves the devolution of powers to the local communities in the conservation and management of natural resources under the government's supervision. However, critical thinkers have argued based on empirical evidences that CBNRM reflects more of rhetoric than success. This study confirms those findings. The many assumptions of CBNRM as conceptualized in theory have been discovered to be violated in the case of Lake Naivasha and as a consequence there is widespread environmental degradation.

Further research is needed to investigate and delineate the vague concept and dimension of the term "community". There is also the need to understand the nature and differences between communicating with the communities and their actual participation in resource management. A lot of questions need more clarification by researchers such as: who actually makes the management decisions? Of whose interest are those decisions been made? Is the state or the so-called experts still control the decisions indirectly? Is the failure of CBNRM projects the fault of a wrongly designed model or is it the problem of implementation? Should the dual aims of achieving conservation goals and community development simultaneously supposed to be incorporated into a CBNRM model? All these answers are necessary to provide lasting solutions to the failures of CBNRM initiatives around the world.

\section{Acknowledgements}

The authors deeply appreciate the support received from Dr Caroline Upton and Dr David Harper of the University of Leicester, UK.

\section{References}

Agrawal, A., \& C.C Gibson. (1999). Enchantment and disenchantment: the role of community in natural resource conservation. World Development, 27, 629-649. http://dx.doi.org/10.1016/S0305-750X(98)00161-2 
Agrawal B. (2001). Participatory exclusions, community forestry, and gender: an analysis of South Asia and a $\begin{array}{llll}\text { conceptual framework. } \quad \text { World development, } & 29(10), & 1623-1648 .\end{array}$ http://dx.doi.org/10.1016/S0305-750X(01)00066-3

Anslem Strauss \& Juliet Corbin. (1998). Basics of Qualitative Research: Techniques and procedures for developing Grounded theory. SAGE Publications, Inc.

Arusei, M.K., Sanga, J. K., \& Tole, M.P. (2003). Outflow of Lake Naivasha based on stable isotope composition of groundwater. In: $2^{\text {nd }}$ KenGen Geothermal Conference, UNEP Headquarters, Nairobi, Kenya.

Avramoski, O. (2004). The role of public participation and citizen involvement in lake basin management. Lake Basin Management Initiative, Thematic Paper.

Barrett C., et al. (2001). Conserving Tropical Biodiversity amid Weak Institutions. BioScience, 51, 497-502. http://dx.doi.org/10.1641/0006-3568(2001)051[0497:CTBAWI]2.0.CO;2

Becht \& Harper. (2002). Towards an understanding of human impact upon the hydrology of Lake Naivasha Kenya. Hydrobiologia, 488, 1-11. http://dx.doi.org/10.1023/A:1023318007715

Becht Robert, et al. (2006). Lake Naivasha: Experienced and lessons learned brief. International institute of Geo-Information Science and Earth Observation (ITC), Netherlands.

Bell, R.G. (2001). The conceptual perspective for public participation. In: The proceedings of the Workshop on Good Governance, Public Participation and the Decision-Making Process for Environmental Protection, Saitharn Publication House, Bangkok, Thailand.

Berkes Fikret. (2004). Rethinking Community-Based Conservation. Conservation Biology, 18(3), 621-630. http://dx.doi.org/10.1111/j.1523-1739.2004.00077

Berkes, F. (2007). Community-based conservation in a globalized world. In: E. Ostrom. ed. Proceedings of the National Academy of Sciences of the United States of America, 104(39), 15188-15193.

Billgren, C., \& Holmen H. (2008). Approaching reality: Comparing stakeholder analysis and cultural theory in the context of natural resource management. Land Use Policy, 25, 550-562. http://dx.doi.org/10.1016/j.landusepol.2007.11.004

Blackstock, K.C, et al. (2007). Developing and applying a framework to evaluate participatory research for sustainability. Ecological Economics, 60, 726-742. http://dx.doi.org/10.1016/j.ecolecon.2006.05.014

Boar, \& Harper. (2002). Magnetic susceptibility of lake sediment and soil on the shoreline of lake Naivasha, Kenya. Hydrobiologia 488. Developments on Hydrobiology, 168, 81-88. http://dx.doi.org/10023/A:1023357910441

Bookrags Staff. (2001). The scientific revolution and philosophical rationalism. [Online] Available: http://www.bookrags.com/research/scientific-revolution-este-0001_0004_01 (15 July, 2010).

Borrini-Feyerband, G. (1996). Collaborative management of protected areas: tailoring the approach to the context. IUCN, Gland, Switzerland.

Bouwen, R., et al. (2004). Multi party collaboration as social learning for interdependence: developing relational knowing for sustainable natural resource management. Journal of community and Applied Social Psychology, 14, 137-153. http://dx.doi.org/10.1002/casp.777

Bradshaw Ben. (2003). Questioning the credibility and capacity of community-based resource management. The Canadian Geographer, 47(2), 137-150. http://dx.doi.org/10.1111/1541-0064.t01-1-00001

Brody S.D. (2003). Measuring the effects of stakeholder participation in the quality of local plans based on the principles of collaborative ecosystem management. Journal of Planning Education and Research, 22, 407-419. http://dx.doi.org/10.1177/0739456X03022004007

Brown, K. (2002). Innovations for conservation and development. The Geographical Journal, 168(1), 6-17. http://dx.doi.org/10.1111/1475-4959.00034

Buanes, A., et al. (2004). In whose interest? An exploratory analysis of stakeholders in Norwegian coastal zone planning. Ocean and Coastal Management, 47, 207-223. http://dx.doi.org/10.1016/j.ocecoaman.2004.04.006

Castro A.P., \& Neilsen, E. (2003). Natural resource conflict management case studies: an analysis of power, participation and protected areas. FAO, Rome. 
Child, B \& M. Lyman (eds). (2005). Natural resource as community assets. Sand County Foundation and The Aspen Institute, Madison, WI.

Cleaver, F. (1999). Paradoxes of participation: questioning participatory approaches to development. Journal of International Development, 11, 11,
$597-612$. http://dx.doi.org/10.1002/(SICI)1099-1328(199906)11:4<597::AID-JID610>3.0.CO;2-Q

Cleaver, F. (2001). Institutions, agency and the limitations of participatory approaches to development. In: B. Cooke and U. Kothari, eds. Participation- the new tyranny? London: Zed Books, 36-55.

Cooke, B., \& Kothari, U. (2001). Participation: The New Tyranny. Zed Books London

Dietz, et al. (2003). The struggle to govern the commons. Science, 302, 1907. http://dx.doi.org/10.1126/science.1091015

Duram, L., \& K. Brown, (1999). Assessing public participation in US watershed planning initiatives. Society and Natural Resources, 12, 455-67. http://dx.doi.org/10.1080/089419299279533

Enniskillen, (2002). The Lake Naivasha Management Plan: Consensus building to conserve an international gem. Hydrobiologia, 488.

Etzioni, A. (1996). Positive aspects of community and the dangers of fragmentation. Development and Change, 27(3), 301-314. http://dx.doi.org/10.1111/j.1467-7660.1996.tb00591.x

Everard M., Harper D.M. (2002). Towards the sustainability of the Lake Naivasha Ramsar site and its catchment. Hydrobiologia, 488, 191-203. http://dx.doi.org/10.1023/A:1023390430571

Everard M., D.M Harper, et al. (2002a). The physical attributes of the Lake Naivasha catchment rivers. Hydrobiologia, 488 (Dev. Hydrobio. 168), 13-25. http://dx.doi.org/10.1023/A:1023349724553

Everard M., D.M Harper, et al. (2002b). Aspects of biodiversity of the rivers in the Lake Naivasha catchment. Hydrobiologia, 488(Dev. Hydrobio. 168), 43-55. http://dx.doi.org/10.1023/A:1023305909532_

Fabricius C. \& Collins S. (2007) .Community-based natural resources management: governing the commons. Water Policy 9 Supplement 2, 83-97. http://dx.doi.org/10.2166/wp.2007.132

Fraser E.D.G et al. (2006) .Bottom up and top down: Analysis of participatory processes for sustainability indicator identification as a pathway to community empowerment and sustainable environmental management. Journal of Environmental Management, 78, 114-127. http://dx.doi.org/10.1016/j.jenvman.2005.04.009

Gaudet, J. (1977). Natural drawdown on Lake Naivasha, Kenya, and the formation of papyrus swamps. Aquatic Botany, 3, 1-47. http://dx.doi.org/10.1016/0304-3770(77)90002-X

Grimble R., \& K. Wellard. (1997). Stakeholder methodologies in natural resource management: a review of principles, contexts experiences and opportunities. Agricultural Systems, 55, 173-193. http://dx.doi.org/10.1016/S0308-521X(97)00006-1

Guijt, I., \& Shah, M.K. (1998). The Myth of Community, Intermediate Technology Publications, London.

Harper et al, (1990). Ecology and management of Lake Naivasha, Kenya, in relation to climatic change, alien species introductions and agricultural development. Environmental Conservation, 17, 328-336.

Harper D.M., Adams, C. \& Mavuti, K.M (1995). The aquatic plant communities of the Lake Naivasha wetland: pattern, dynamics and conservation. Wetland Ecology and Management, 3, 111-123. http://dx.doi.org/10.1007/BF00177693

Harper D. M., \& Mavuti, K. M. (2004). Lake Naivasha, Kenya: Ecohydrology to guide the management of a tropical protected area. Ecohydrology \& Hydrolobiologia, 4, 287-305. ftp://ftp.itc.nl/pub/naivasha/Harper2004.pdf

Harper D. M., \& Mavuti K. M., et al. (2002). Phosphorus inputs to Lake Naivasha, Kenya, from its catchment and the trophic state of the lake. Hydrobiologia, 488, 73-80. http://dx.doi.org/10.1023/A:1023362027279

Harper D.M., \& Becht R, (2002). Towards an understanding of human impact upon the hydrology of Lake Naivasha, Kenya. Hydrobiologia, 488, 1-11. http://dx.doi.org/10.1023/A:1023318007715

Harper D.M., et al. (2010, unpublished). A sustainable future for Lake Naivasha, Kenya, conflicts between ecology, economy and conservation

Hellstrom, E. (2001). Conflict cultures: Qualitative comparative analysis of environmental conflicts in forestry. Silva Fennica, 2: 1-109. The Finnish Society of Forest Science and The Finnish Forest Research Institute. 
Hickley. et al. (2004). Habitat degradation and subsequent fishery collapse in Lakes Naivasha and Baringo, Kenya.Unpublished, available at: http://www.le.ac.uk/bl/staff/dmh/dmhearthwatch.htm.

Hotte, C. (2001). Conflict over property rights and natural resources exploitation at the frontier. Journal of Development Economics, 66: 1-21. http://dx.doi.org/10.1016/S0304-3878(01)00153-5

Jordan, A., Volger, J. (2003). Governance and environment. In: F. Berkhout, M. Leach and Scoones, Eds. Negotiating environmental change: new perspectives from social science. Northampton: Edward Elgar, 137-158.

Koch, E. (2004). Putting out fires: does the "C" in CBNRM stands for community or centrifuge? In: Fabricius, C. $\&$ Koch, E. (eds). Rights, Resources and Rural Development: Community-Based Natural Resource Management in Southern Africa. Earthscan, London, pp. 78-92.

Kates, R.W., et al. (2001) .Sustainability Science. Science, 292, 641-642. http://dx.doi.org/10.1126/science.1059386

Kumar C. (2005). Revisiting "Community" in community-based natural resource management. Oxford University Press and Community Development Journal, 40(3), 275-285. http://dx.doi.org/10.1093/cdj/bsi036

Leach, M., Mearnes, R., \& Scoones, I. (1999). Environmental entitlements: dynamics and institutions in community-based natural resource management, World Development, 27(2), 225-247. http://dx.doi.org/10.1016/S0305-750X(98)00141-7

Matzke, G.E., \& Nabane, N. (1996). Outcomes of a community controlled wildlife utilization program in a Zambezi Valley community. Human Ecology, 24(1), pp. 65-85. http://dx.doi.org/10.1007/BF02167961

McCool, S., \& Guthrie, K. (2001.) Mapping the dimensions of successful public participation in messy natural resource management situations. Society \& Natural Resources, 14, 309-23. http://dx.doi.org/10.1080/713847694

Moote, \& Conley (2003). Evaluating collaborative natural resource management. Society \& Natural Resources, 16, 371-386. http://dx.doi.org/10.1080/08941920390190032

Morrison, E.H.J., \& Harper, D.M. (2009). Ecohydrology principles to underpin the restoration of cyperus papyrus at Lake Naivasha, Kenya. Ecohydrology \& Hydrobiology, 9(1), 83-97. http://dx.doi.org/10.2478/v10104-009-0036-6

Nhantumbo I., et al. (2003). Community-based natural resource management in Mozambique: A theoretical or practical strategy for local sustainable development? The case study of Derre Forest Reserve. Sustainable livelihoods in Southern Africa Research paper 10, Institute of Development studies Brighton.

Paul-Wostl, C., et al. (2007). Social learning and water resources management. Ecology and Society, 12(2), 5. http://www.ecologyandsociety.org/vol12/iss2/art5/

Pretty, J., Guijt, I (1992). Primary environmental care: an alternative paradigm for development assistance. Environment and Urbanization, 4(1), 22-36. http://dx.doi.org/10.1177/095624789200400104

Reed, M., (2008). Stakeholder participation for environmental management. Biological Conservation, 141, 2417-2431. http://dx.doi.org/10.1016/j.biocon.2008.07.014

Republic of Kenya, (2004). Ministry of Environment and Natural Resources. Third National Report on the implementation of UNCCD, National Environment Management Agency (NEMA).

Sanginga, P.C., et al. (2007). The dynamics of social capital and conflict management in multiple resource regimes: a case study of the South western highlands of Uganda. Ecology \& Society, 12(1), 6. http://www.ecologyandsociety.org/vol12/iss1/art6/

Sarin, M. (1995). Joint forest management in India: Achievements and unaddressed challenges. Unasylva 180(46), 30-36. [Online] Available: http://www.fao.org/docrep/v3960e/v3960e06.htm

Schmigel, P. (2005). Pointing the way to successful stakeholder engagement, WME Environment Business Magazine, 16.

Shackleton, C.M., WillisS, T.J., Brown, K. \& Polunin, N.V.C. (2010). Reflecting on the next generation of models for community-based natural resources management. Environmental Conservation, 37(1), 1-4. http://dx.doi.org/10.1017/S0376892910000366

Shackleton, S. E., et al. (2002). Devolution and Community-based natural resource management: creating space for local people to participate and benefit? Overseas Development Institute (ODI), No. 76. 
Schumacher, E. (1973). Small is beautiful: a study of economics as if people mattered. London: Blond and Briggs.

Smith, Julia L. (2008). A critical appreciation of the bottom-up approach to sustainable water management: embracing complexity rather than desirability. Local Environment, 13(4), 353-366. http://dx.doi.org/10.1080/13549830701803323

Richards, C., et al. (2004). Practical approaches to participation, SERG Policy brief No.1, Macauley Land use Research Institute, Aberdeen.

Verschuren, D., et al. (2000). Rainfall and drought in equatorial East Africa during the past 1,100 years. Nature, 403, 410-414. http://dx.doi.org/10.1038/35000179

Verschuren, D. (2001). Reconstructing fluctuations of a shallow East African lake during the past 1800 years from sediment stratigraphy in a submerged crater basin. Journal of Palaeolimnology, 25(3), 297-311. http://dx.doi.org/10.1023/A:1011150300252

Warner M., Jones P. (1998). Assessing the need to manage conflict in community-based natural resource projects. Overseas Development Institute (ODI). No 35.

Wijnands, J. (2005) Sustainable International Networks in the Flower Industry-Bridging empirical findings and theoretical approaches. Scripta Horticulture, No.2.

WildLife.com, (2011). Lake Naivasha is threatened by rampant water usage. [Online] Available: http://www.wildlifeextra.com/go/news/bn-naivasha.html\#cr (15 September 2011).

Yasmi, Y. (2004). Natural resources conflict management case studies: an analysis of power, participation and protected areas. FAO. Rome. Forest Ecology and Management, 193(3), 427-428. http://dx.doi.org/10.1525/aa.2004.106.4.754

Yossie, T. \& Herbst, T. (1998). Using stakeholder processes in environmental decision making: An evaluation of lessons learned, key issues, and future challenges. Washington, D.C Ruderfinn Washington.

Table 1. Importance of Lake Naivasha to the Community

\begin{tabular}{ccc}
\hline Nature of Benefit & Frequency & Percentage \\
\hline Source of Food & 21 & 30.8 \\
Indirect Benefits e.g. raw material, drainage, power generation e.tc. & 18 & 26.4 \\
Fishing as a Source of Income & 12 & 17.6 \\
Domestic Consumption & 11 & 16.3 \\
Employment & 4 & 5.8 \\
Tourism and Recreation & 2 & 2.9 \\
\hline Total & 68 & 100 \\
\hline
\end{tabular}

Number of respondents $(\mathrm{n})=40$.

Table 2. Factors Affecting the Lake Hydrology

\begin{tabular}{ccc}
\hline Causes & Frequency & Percentage \\
\hline Drought & 28 & 37.8 \\
Flower Farming & 17 & 22.9 \\
Over use of Lake Water & 15 & 20.1 \\
Catchment Destruction & 6 & 15 \\
Habitat Destruction & 4 & 8.1 \\
Not Sure & 4 & 8.1 \\
\hline Total & 74 & 100 \\
\hline
\end{tabular}

Total number of respondents $(n)=40$. 


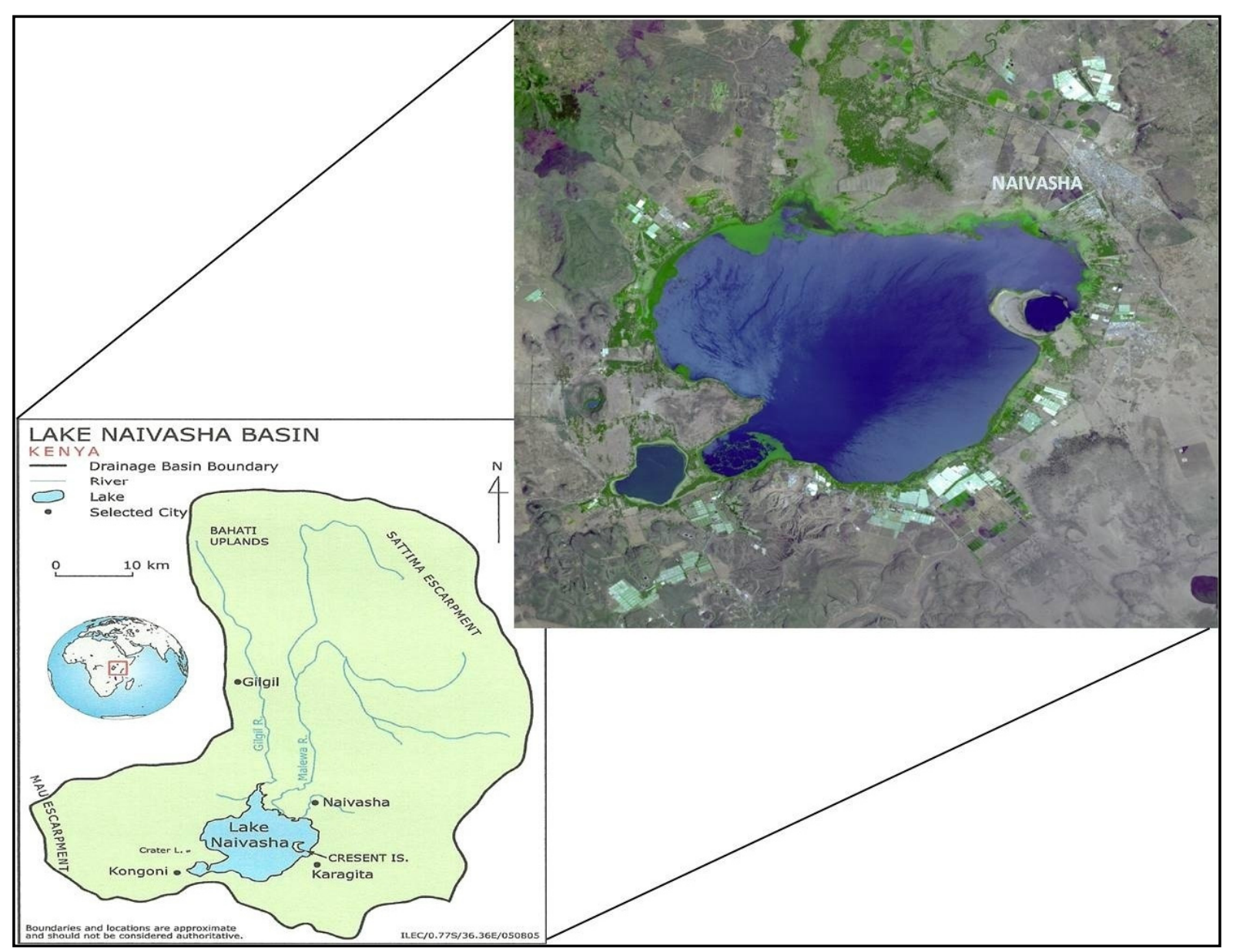

Figure 1. Lake Naivasha, Kenya

Source: Map from Becht R. et al. (2006) and satellite image from: http://www.treehugger.com/lake-naivasha.jpg

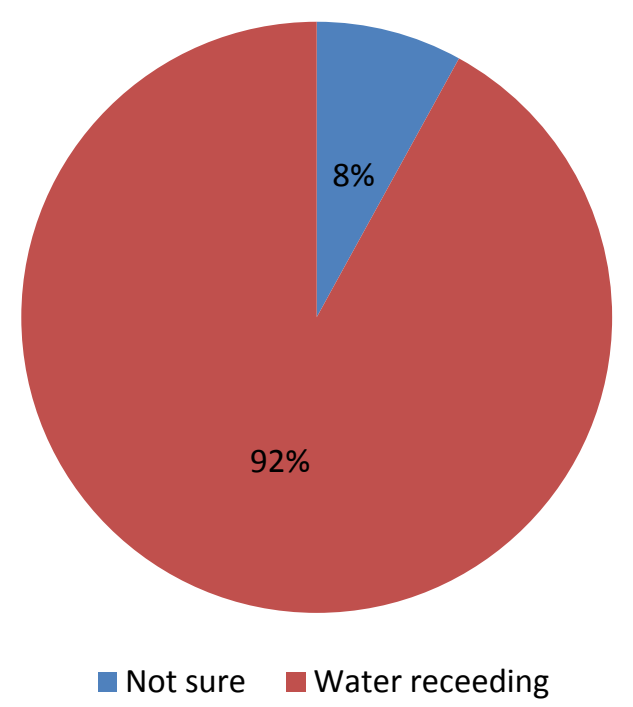

Figure 2. Changes in the Hydrological Status of Lake Naivasha

Total number of respondents $(n)=40$. 


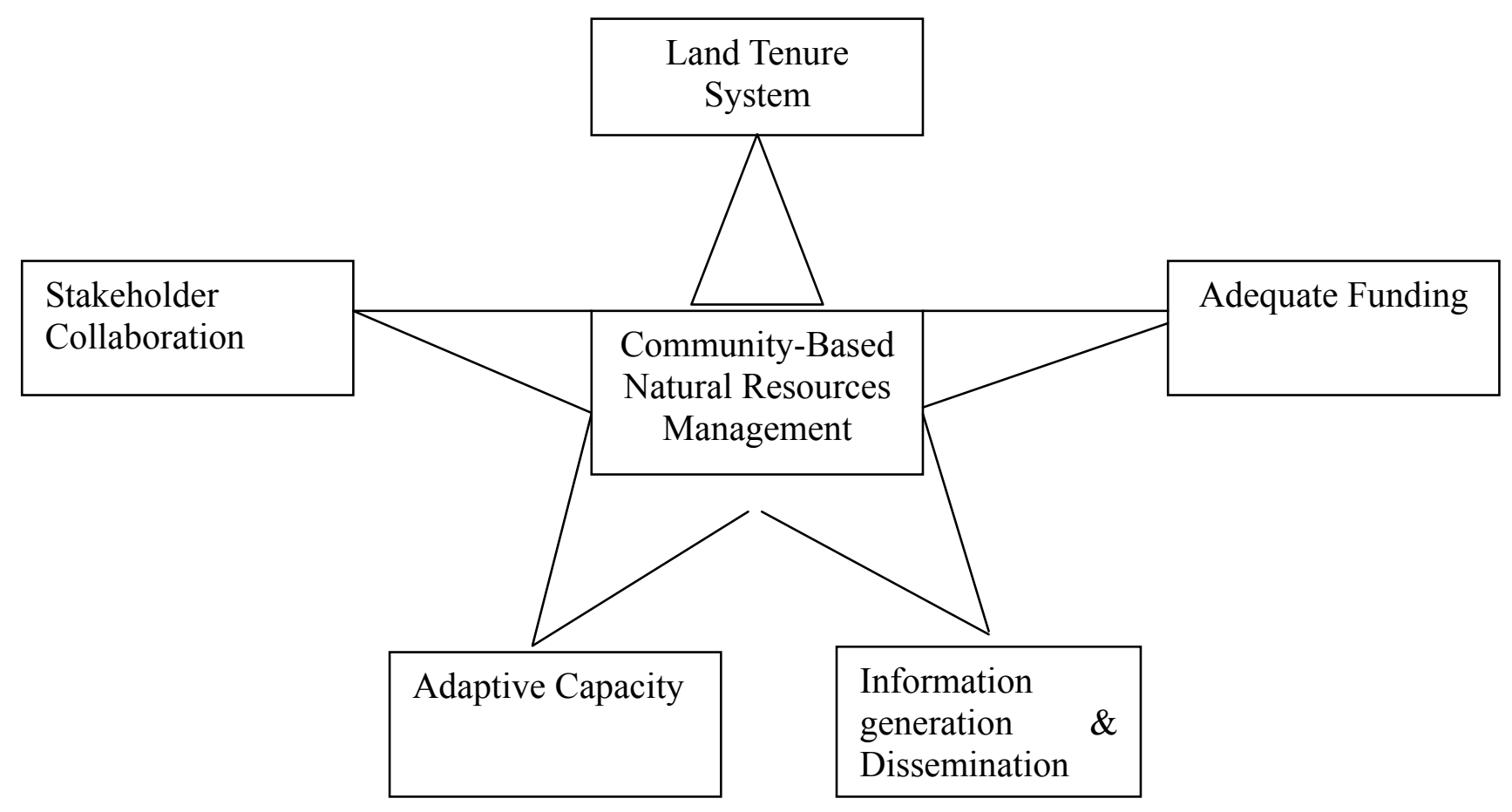

Figure 3. A Conceptual Model for Assessing CBNRM at Lake Naivasha 